Article

\title{
From Preferential Trade Arrangements to Free Trade Agreements: One of the Downturns of Cooperation in International Relations?
}

\author{
Jose Jaime Baena-Rojas $1, *$ (D) and Susana Herrero-Olarte ${ }^{2, *(D)}$ \\ 1 School of Management, Institución Universitaria CEIPA, Medellín 05001, Colombia \\ 2 Faculty of Economics and Business (FACEA), Universidad de Las Américas, Quito 170102, Ecuador \\ * Correspondence: jose.baena@ceipa.edu.co (J.J.B.-R.); susana.herrero@udla.edu.ec (S.H.-O.)
}

Received: 14 May 2020; Accepted: 18 July 2020; Published: 6 August 2020

check for updates

\begin{abstract}
Since the signing of the General Agreement on Tariffs and Trade (GATT) and the creation of the World Trade Organization (WTO), preferential trade agreements (PTAs) have been an interesting tool to promote international cooperation through the granting of non-reciprocal and/or unilateral tariff preferences by developed countries to developing countries. These international agreements have tended to generate critical trade dependencies for the receiving countries. Due to the circumstances of world trade and due to the lack of interest of the grantors to maintain this type of tariff preference, these developing countries are forced to renegotiate their PTAs into to free trade agreements (FTAs). To demonstrate this, we conducted a qualitative analysis to characterize the behavior of PTAs and their impact on the configuration of FTAs and to obtain indicators and trends. The results suggested a predominance of FTAs and a decline in PTAs. This was done to maintain access to the markets within those granting countries, which also became the main trading partners of these PTA recipient countries.
\end{abstract}

Keywords: preferential trade agreements; free trade agreements; international cooperation; multilateral trading system; international relations

\section{Introduction}

Historically, preferential trade agreements (PTAs) have been regarded as a type of international treaty in which a country grants tariff preferences to either one or several countries, with the latter not obliged to offer any kind of tariff benefit to their counterpart in return. In other words, within PTAs, unilateral concessions are generally granted by developed countries in terms of a full or partial reduction in customs taxes on certain products that may be likely to be imported from such developing countries (OECD 2005; WTO 2019a).

Thus, it can be said that PTAs can be understood as a way in which special and differential treatment (S\&D) is applied, consisting of the adoption of asymmetric trade liberalization measures and programs that typically end up reflecting non-reciprocal trade preferences among different states within the international political system (Giordano et al. 2004).

In fact, $S \& D$, by definition, highlights the dynamics of international relations among countries with dissimilar levels of development. By default, this leads to negotiating commercial schemes of non-reciprocal, concessional treatment in order to favor those countries with development problems, with the purpose of enhancing their growth and subsequently facilitating their insertion into world trade. Given its relevance, S\&D was, hence, incorporated as a principle into Article XVIII "Governmental Assistance to Economic Development" when the General Agreement on Tariffs and Trade (GATT) was created-and still acts as the main legal system in the current Multilateral Trading System led by the World Trade Organization (WTO) (Diez 2001). 
Authors, such as Büthe and Milner (2008), argued precisely that traditionally developing countries that receive tariff benefits through PTAs usually also implement mechanisms to engage with foreign investors concerning the treatment of their assets, which collaterally enables developing countries to attract more foreign investment and, therefore, boost their own economic growth. In this way, it can be said that with relevant episodes, such as the plans to rebuild Europe after the end of World War II, the emergence of the United Nations (UN), and the decolonization process, international cooperation took a leading role in international relations. This was due to countries adopting mechanisms to transfer monetary resources directly to a recipient country, in order to improve their development indicators. However, cooperation is to be analyzed from a human development perspective that goes far beyond a mere economic vision (Duarte and González 2015).

In this article, we aim to describe, after the end of the Second World War, the behavior of PTAs when international cooperation was consolidated with the role of the UN. We also aim to highlight how many of these PTAs, understood as trade agreements, have become free trade agreements (FTAs), which show a weakening of the S\&D within the Multilateral Trading System and therefore an evident decline in cooperation in international relations. Regarding this phenomenon where PTAs tend to shift to FTAs, the situation responds to the new interest of certain developed countries in reducing their aid and tariff preferences to other developing countries. This can be explained partly by the current dynamics of the international system where countries adopt protectionist measures in order to safeguard their economic interests. In this sense, some states appear reluctant depending on the expected costs and even opportunism within international relations, as they consider their capacity for political-economic action to be limited within the world government paradigm (Lake 1996, 2009, 2011; Martin 2015; Fernández 2009). It is necessary to consider the possible effects of the great recession on this type of support program with the unilateralism of some developed countries (Baldwin and Evenett 2008; Rosales 2009; Evenett and Fritz 2018) and the expected worsening of protectionism within international trade (Baena et al. 2017; Baena and Londoño 2020).

On the basis of the above, is it possible to state that the shift of PTAs to FTAs is undermining the S\&D and to also reveal the decline in cooperation in international relations in this regard? Along these lines, this research proposal opens the debate on how cooperation shows a significant change in the dynamics at present, as well as how certain developed countries that grant not only capital transfers but also particular unilateral tariff preferences through PTAs may end up generating a significant commercial dependence in the beneficiary developing countries. The foreign trade policy of all parties may be conditioned in the medium and long terms, in addition to becoming an instrument of pressure for developing countries so that developed countries can move forward in achieving specific objectives relating to their own political interests (Lavopa 2012).

The type of study is outlined in the methodology section and the sources used are also presented, which are mainly supported by the WTO's "Preferential Trade Agreement" database, whose content guarantees a high level of veracity for the present analysis given its remarkable reliability. The development of schemes and tables is consequently proposed in the results section in order to present, in a more dynamic way, how the theoretical behavior of PTAs, FTAs, and cooperation in international relations is currently described. Then, the conclusions are presented in the final section of this work in addition to recommendations and future lines of research deriving from the present scientific research proposal.

\section{Literature Review}

\section{Preferential Trade Agreements (PTAs) and Their Relationship within International Cooperation}

Trade agreements have become one of the most relevant, studied phenomena in the international economy for boosting trade interchange and to take advantage of the specialization and cost advantages offered by each country. In this way, trade agreements can face specific, harmful effects from excessive protectionism, which often leads to problems of inefficiency, as this may allow companies to survive 
that end up incurring higher costs than necessary. On the other hand, this may generate inefficiencies in consumption because consumers are displaced from the market who would be willing to pay what it costs to produce that item without the artificial overpricing of the tariff. Therefore, currently there exists a growing enthusiasm of many countries seeking to reduce certain protectionist trends characterized by the excessive use of tariff and non-tariff barriers within trade flows worldwide. Researchers estimated that approximately half of the world's trade is carried out among countries that have managed to implement these types of agreements. Then, this approach for liberalizing the economies of protectionism is a widespread foreign policy instrument that promotes the process of economic integration reducing the latent protectionism within the current globalization model (Tugores 2002; Estevadeordal and Suominen 2009; Vanegas and Baena 2019).

In general terms, Hassan (2001) also stated that trade agreements are essentially a precedent for a potential integration of countries as trade liberalization not only aims to strengthen relations but can also offer significant gains for the parties that intervene in the process by eliminating tariff and non-tariff barriers within the general framework of trade agreements. Additionally, as Trejos (2009) argued, trade agreements, in addition to promoting tariff reduction and eliminating other non-tariff barriers, also allow for the reallocation of productive factors in each country as well as encouraging changes in production, consumption, exports, imports, and even influencing the price of all factors and goods of the parties involved. Another relevant and still relatively unknown feature of international agreements is related to the creation of specific norms that can regulate a large number of issues that are not clear in the WTO legal system. This occurs with export restrictions and other similar trade matters (Baena 2019).

According to Bearce (2003), trade agreements can also help reduce the incidence of interstate conflicts of a political nature due to the advantages they offer in terms of new business opportunities; this is why the participating governments ponder the potential benefits that the agreements may bring in the future. This occurs through a dialogue focused on social development, which can both foster trust between the parties and allow the creation of specific commitments delving into matters other than what is exclusively commercial within this type of international agreement.

Consequently, there is an important background that renders the dynamics of trade agreements subject to the governance model within contemporary international relations. In this case, non-commercial aspects of increasing scope in the participating countries' agenda are involved, as happens with the consolidation of democracy, human rights, the environment, and corruption and labor standards, among other issues increasingly linked to the signing of these agreements (Milewicz et al. 2018). Precisely those states with more consolidated democracies tend to be more likely to participate in the dynamics of free trade. In this sense, it may be asserted that interstate cooperation in trade matters depends largely on the type of political regime of the participating countries since, as states become more democratic, they are more likely to conduct mutual trade agreements. In fact, the empirical evidence in this regard suggests that, after the Second World War, the most consolidated democracies have effectively been those that have created the most agreements of this type, given that they are actually more commercially cooperative than less democratic countries (Mansfield et al. 2002a, 2008).

In this vein, according to Duarte and González (2015), the international system has become crucial for international cooperation and state development today. A complex network of actors, institutions, bodies, and even mechanisms have been formed to achieve this goal. The United Nations (UN) is one of these outstanding actors, which is primarily sustained by the diversification of its international agenda, which goes far beyond economic and security issues. The $\mathrm{UN}$ also promotes friendly relations among nations, seeks to achieve international cooperation to solve global problems, and serves as a center that harmonizes the actions of states around the world.

In this way, the UN currently represents one of the most important strategic efforts in the history of international relations; since within this international organization, in which most of the countries of the world are represented, it constitutes a forum for dialogue and discussion between countries. The UN is currently the most effective instrument for attempting to find solutions to global problems, 
in the field of economic, social, political, cultural, demographic, and geographical development issues, among other social issues. However, the willingness to cooperate in international economic relations is not the result of a few days, but the result of a long process and is not exempt from tensions (Ugarte Vega-Centeno 1996).

We clarify that international treaties-even those of a commercial nature, as in the case in point-are regulated by the 1969 Vienna Convention, which establishes the legal system that delimits all the key elements concerning the validity of this type of agreement among states and/or international organizations. Similarly, there are different types of trade agreements, not only according to the number of members they have, their length, object, and purpose, but also even depending on the reciprocity based on the granting of tariff preferences (Sánchez 2010; Pardo 2014; Baena and Cardona 2019).

For this reason, we suggest that there are different types of trade agreements (see Table 1), which can be understood as an association of countries and/or commercial blocks that seek to liberalize trade either reciprocally or non-reciprocally, under a set of explicit conditions regarding access to specific markets. Such association can thereby also be, in broad terms, unilateral, bilateral, or multilateral (Kembayev 2009; WTO 2011; De Boyrie and Johns 2013; Missios et al. 2016).

From the sources mentioned above and according to Kennedy (2011), PTAs and/or preference laws have historically been a striking type of trade agreement considering that after GATT was formed as a legal system in 1947-in an attempt to establish international standards for conducting world trade-the view that the principle of equal treatment among countries was inadequate if countries were not equal economically speaking was finally accepted. This situation also resulted in the insertion of S\&D into GATT Article XVIII "Governmental Assistance to Economic Development”, an agreement that, at the time, was certainly not very enthusiastically received among developing countries; the latter saw this agreement as an elite club whose promises of free trade became unsubstantial. This prejudice gradually changed during all eight GATT rounds given that $S \& D$, and therefore the possibility for many developed countries to create and grant PTAs to developing countries, also started to be included as a set expression in several GATT articles, legitimizing the opinion that developing countries should be treated differently due to their economic circumstances.

Similarly, concerning the GATT negotiation rounds, it is necessary to highlight that, on the one hand, they managed to clarify some possible discrepancies between Articles I "General Most-Favored Nation Treatment" and XXIV "Territorial Application-Frontier Traffic-Customs Unions and Free Trade Areas" of the GATT as a legal system. These potential inconsistencies often impacted the legitimacy of international trade agreements, including PTAs (Cardona 2015; Lacarte and Granados 2004). The negotiation rounds, on the other hand, also made substantial contributions at the level of the legal provision that allowed GATT to be supplemented with several complimentary legal texts.

This first contribution happened in the Tokyo Round (1973-1979), where the "Enabling Clause" was also created, making it possible to reach trade agreements among developing countries to eliminate barriers to trade, without eroding the principle of the most-favored nation (MFN). Another relevant contribution happened in the Uruguay Round (1986-1994), which ended up as the precursor to the WTO and the current multilateral trading system as it stands today (De la Reza 2015; Cardona 2017; Baena and Fernández 2016). Therefore, the empirical evidence suggests that PTAs can generate higher industrialization, an increase in the trade flows, and a clear economic development as a basic positive effect in countries that receive this type of tariff preference. However, developed countries that offer this benefit to developing countries are aware that this trade policy can also be, in time, a potential disadvantage for their national interest and their domestic companies (Ito and Krueger 1993; WTO 2011). 
Table 1. Types of trade agreements within the multilateral trading system.

\begin{tabular}{|c|c|c|c|}
\hline Types of Agreements & Regulation & Generalities & Information Sources \\
\hline $\begin{array}{c}\text { Preferential trade agreements (PTAs) } \\
\text {-Unilateral- }\end{array}$ & $\begin{array}{c}\text { Vienna Convention on the Law of } \\
\text { Treaties -1969- } \\
\text { United Nations (UN) }\end{array}$ & $\begin{array}{l}\text { These trade agreements are also known as "preference law } \\
\text { and/or unilateral tariff preferences" and are characterized } \\
\text { by the fact that one of the two participating parties—usually } \\
\text { a developed economy—grants full or partial nonreciprocal } \\
\text { tariff preferences on the tariff universe of products from the } \\
\text { beneficiary country—usually a developing economy. }\end{array}$ & $\begin{array}{l}\text { (Piérola 2002; Panagariya 2002; Rose 2004; } \\
\text { Kolb 2008; USTR 2018; WTO 2019a; CBP 2020) }\end{array}$ \\
\hline $\begin{array}{l}\text { Partial scope }{ }^{1} \text { agreements (PSAs) } \\
\text {-Bilateral- }\end{array}$ & $\begin{array}{c}\text { General Agreement on Tariffs and Trade } \\
\text { (GATT) } \\
-1947 \text { and 1994- } \\
\text { World Trade Organization (WTO) }\end{array}$ & $\begin{array}{l}\text { These trade agreements are also known as "economic } \\
\text { complementation agreements" according to their } \\
\text { liberalization level and are characterized in that their } \\
\text { parties grant each other reciprocal and partial tariff } \\
\text { preferences on the tariff universe of products from the } \\
\text { participating countries; these, however, are eventually } \\
\text { expected to turn into full preferences. }\end{array}$ & $\begin{array}{l}\text { (Fiorentino et al. 2007; Cheong et al. 2018; } \\
\text { SUBREI 2019; WTO 2019b; UNESCAP 2019) }\end{array}$ \\
\hline $\begin{array}{l}\text { Free trade zones (FTZs) } \\
\text {-Bilateral- }\end{array}$ & $\begin{array}{l}\text { Art. I "General Most- Favored Nation } \\
\text { Treatment," Art. III “National Treatment } \\
\text { of Internal Taxation and Regulation," } \\
\text { and Art. XXIV “Territorial } \\
\text { Application-Frontier Traffic-Customs } \\
\text { Unions and Free Trade Areas." }\end{array}$ & $\begin{array}{l}\text { These agreements are also known as "free trade agreements } \\
\text { (FTAs)" and are characterized in that their two parties grant } \\
\text { each other, as a general rule and in most cases, full, } \\
\text { reciprocal tariff preferences on the tariff universe of the } \\
\text { products from the participating countries. }\end{array}$ & $\begin{array}{c}\text { (Hollenberg 2003; Ajami et al. 2006; Baier and } \\
\text { Bergstrand 2007; Baena 2018; Ramadan 2010; } \\
\text { WTO 2019a; SUBREI 2019) }\end{array}$ \\
\hline $\begin{array}{l}\text { Customs Unions (CUs) } \\
\text {-Multilateral- }\end{array}$ & $\begin{array}{c}\text { Enabling Clause } \\
-1979- \\
\text { Tokyo Round }\end{array}$ & $\begin{array}{l}\text { These agreements are also known as "economic } \\
\text { integrations" and are characterized in that their three or } \\
\text { more parties grant each other full, reciprocal tariff } \\
\text { preferences on the tariff universe of the products from the } \\
\text { participating countries. Given the complexity, matters that } \\
\text { go beyond the merely commercial are present within this } \\
\text { type of agreement, such as economic matters, monetary } \\
\text { affairs, social issues, immigration issues, and even political } \\
\text { matters, which are addressed to different extents or } \\
\text { integration levels over time within a complex } \\
\text { supra-nationality model. }\end{array}$ & $\begin{array}{l}\text { (Kemp and Wan 1976; Whalley 1998; } \\
\text { Jovanović 1998; Bartels and Ortino 2006; } \\
\text { Balassa 2013; European Parliament 2018) }\end{array}$ \\
\hline
\end{tabular}

Source: Own elaboration.

1 Even though the commercial agreements in this compendium may seem questionable, the fact that theorists, such as Fiorentino et al. (2007), evaluated this category in studies on this subject and analyzed their effects within international trade is to be highlighted. PSAs can be understood simply as an initial stage of liberalization among certain countries that hope to materialize FTAs eventually. 
In this vein, according to Cassimatis (2011), PTAs have traditionally been considered an important instrument to formally link international trade and other social issues, including human rights, labor rights, and civil rights, among other matters. This can be understood as an attempt, by developed countries, to promote overall growth and likewise to boost cooperation within international relations. However, the overall picture is still bleak given that the world economy has failed to recover its growth levels after the Great Recession of 2008. This event undoubtedly affected international cooperation trends, paradoxically leading developed countries to withdraw the tariff preferences from PTAs and also to restrict their capital flows, seeking to safeguard their interests. In this way, this scenario can prevent the normal dynamics of economic growth within the model of international relations itself (Cassis 2011; Acharya and Bengui 2018).

It is ultimately safe to assert that the possibility of improving the welfare of developing countries through the logic of cooperation and the granting of PTAs lies in the occurrence of three key aspects. The first is the relationship between the preferential access to certain products and the export performance of such products; the second is the relationship between the increase in manufacturing exports and the industrialization level; and last is the industrialization promoted by exports and the economic welfare of developing nations. Therefore, the success of these commercial agreements depends on only the fulfillment of these three circumstances (Sapir 1981).

Axelrod and Keohane (1985) concurred with the idea that cooperation does not equate to harmony within international relations as the latter requires a full identity of interests among the parties, whereas cooperation can only occur in situations that deal, in turn, with a mixture of conflicting interests and complementary interests. Consequently, cooperation among countries is evidenced when the actors adjust their behavior to the actual or anticipated preferences of others, which is why cooperation is not necessarily considered morally good within international relations-this is also characterized by the absence of a common world government that fully regulates all these interests.

Cooperation results are yet to reach expectations, even though there is a multilateral trading system attempting to regulate the relations among its member countries in this sense, as well as promoting S\&D and the very principle of the MFN clause to protect the interests of developing countries within its parameters of differential market access through PTAs. Despite considering the fragility of the developing countries' unity, the GATT-WTO paradigm appears to be experiencing a significant stagnation in recent years. This is hindering progress on important issues in its agenda and is caused by the lack of consensus among developed and developing countries, the latter having a shortage of the necessary resources to use traditional instruments of power in international relations, despite being a majority (Dos Santos et al. 2005).

Additionally, PTAs have faced key criticism because, in the first place, it is assumed that the export sectors of the recipient countries of these agreements tend to be the greatest beneficiaries within the structure of foreign trade, compelling the sector to put less pressure on national protectionism, resulting in greater trade barriers in the country. In other words, it may be suggested that the interaction between the GATT-WTO paradigm and the PTA tool to liberalize trade and promote cooperation can negatively affect the import sector, which clearly undermines the normal development of trade in countries (Tobin and Busch 2019). Secondly, Piérola (2002) similarly stated that the concessions resulting from PTAs raised strong questions regarding the legitimate scope of the S\&D principle, due to the fact that the implementation of tariff preferences created by these unilateral trade agreements has only been applicable to a few developing countries instead to all developing countries, which violates the MFN principle. In fact, regarding this situation and the differentiated tariff treatments, there have been official conflicts in the past within the WTO dispute settlement mechanism, where the breach of GATT Article I has been argued.

However, the strongest criticism, in the third place, deals with how PTAs can crack the sovereignty of less developed countries. Certain economic powers granting non-reciprocal economic preferences may potentially be searching for some kind of consideration that constitutes an element of pressure for political purposes in order to spur the support of the countries receiving these benefits in various 
aspects. The latter countries may even adopt public policies that follow the same direction as the international agendas of the developed countries granting the preferences (Lavopa and Dalle 2012).

Along these lines, Bartels (2003) added that given the current circumstances of the world economy, after the Great Recession and with the stagnation of the multilateral trading system, certain developed countries adopted a new foreign trade policy approach. This means setting aside international cooperation as an economic instrument for the unilateral granting of preferences derived from the PTAs. Hence, these types of trade agreements are no longer compatible with the new shift toward non-reciprocity with developing economies. That is why developed economies tend to renegotiate their current PTAs shifting to FTAs, where the tariff preferences are reciprocal in this last type of trade agreement.

Thereby, the economic literature has addressed several explanations for the incentive for countries to sign FTAs, among which is essentially the boom with respect to regionalism (Bhagwati 2008). Mansfield et al. (2002b) and Wu (2004) addressed this increase in FTAs due to the spread of democracy; while Mansfield and Pevehouse (2000), Martin et al. (2010), and Vicard (2008) addressed the issue of geopolitical stability. Thus, this approach determined the reduction in PTAs and had an adverse effect on the multilateral trading system (Bhagwati 2008).

In this context, there also exists the domino theory of regionalism where the increase in FTAs may generate an incentive for countries to seek to sign FTAs as a measure to correct the growing discrimination concerned with being outside this trading trend. Therefore, the signed FTAs create a trend that may lead to new agreements of this type. This raises the possibility that FTAs are contagious, where for example; a new FTA between two countries increases the likelihood that a third nation will sign a new FTA with one of the two previous countries (Baldwin 1993; Baldwin and Jaimovich 2012).

On the other hand, there is another line that suggests that the failure of the Doha Rounds may be the possible cause of the increase in trade agreements, both FTAs and other regional trade agreements (RTAs). Although the data showed an increase in both FTAs and RTAs, there is a lack of clarity regarding the counting of FTAs considering the accessions of new members within the RTAs total inventory. Thus, the data may be deficient in including cases where these types of trade agreements are considered together. There is also a line of thinking that suggests that the formation of PTAs responds to the simple need for development in trade management and relationship agreements due to the complex global convergence regarding world integration (Hartman 2013; Baena 2020).

Consequently, the situation mentioned above is explained not only by the reciprocity offered by FTAs in terms of tariff reductions but also by the fact that these trade agreements, which have become quite popular in recent years, offer other special features relating to flexibility in negotiation, the possibility of including various commercial issues (such as services), as well as the likelihood of the parties to reach an agreement on legal commitments outside the WTO. The latter, is especially important considering that the WTO-with its current institutional problems-does not fully regulate specific issues pertaining to international trade (Bhagwati and Panagariya 1996; Urata 2002; Crawford and Laird 2001; Kinoshita and Barbosa 2016).

\section{Methodology}

Initially, and at the methodological level, a complete review of the literature was conducted with the purpose of identifying articles, books, specialized websites, and related research that recognized the main characteristics of PTAs in the multilateral trading system. Here, we stress that these are regulated at the legal level by Article XXIV "Territorial application-Border traffic customs unions and free trade areas" of the GATT as well as the Enabling Clause of the 1979 Tokyo Round.

Similarly, a descriptive study on PTA influences within the current cooperation paradigm in international relations was performed. For the construction of the theoretical framework and/or review of the literature, it was essential to investigate "The impact of PTAs within the economic cooperation of countries and their relationship within international trade". The foregoing has the aim of contextualizing why these types of international agreements are increasingly losing prominence. 
This was done while considering the current dynamics of international trade, where unilateral tariff concessions are becoming less common and where FTAs take on a special role in breaking down the ideal of cooperation that PTAs traditionally tended to promote.

The database of the WTO on PTAs-in which all international agreements of this nature are deposited-was examined and identified, seeking to evidence and characterize the behavior of PTAs, highlighting their incidence in the configuration of FTAs within the multilateral trading system. In this sense, the current research conducted a qualitative study in the terms of Quecedo and Castaño (2002), where descriptive information is analyzed and the observable behavior of the researcher is presented, who formulates possible explanations regarding specific phenomena. That is, this type of research is inductive. Within this type of research, see Figure 1, concepts are understood and developed based on data patterns, and not by collecting data to evaluate hypotheses or preconceived theories. Similarly, within this approach, we emphasize the validity of the research through an empirical approximation that reliably legitimizes potential explanations without reaching generalizations or absolute statements.

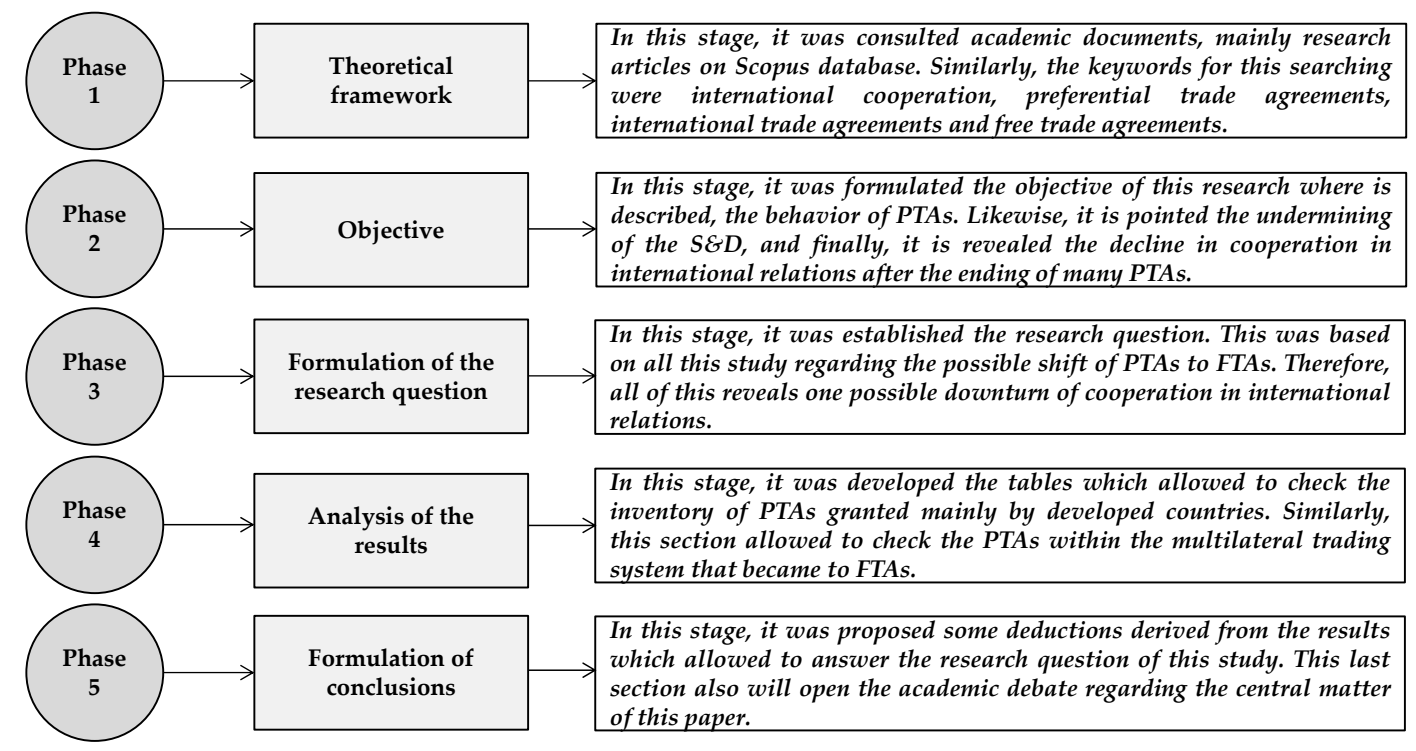

Figure 1. Phases of the research for the current subject of study. Source: Own elaboration based on Quecedo and Castaño (2002); Healy and Perry (2000) and Giddens and Phillip (2013).

Subsequently, in the last part of the methodological level, the results are proposed, and, through a general qualitative analysis, indicators and trends are presented. Here, the predominance of FTAs and the decline in PTAs can be observed. Thus, the relevance of the different techniques for social research, typically supported by a qualitative approach, depends on the observation phenomena for analysis. Implications in epistemological terms should also be considered. We performed this research to produce new reflections and contributions to the knowledge in a specific field of social sciences to strengthen academic discussion (Denzin and Yvonna 2005; Gisselquist 2014).

\section{Results and Discussion}

After conceptually describing PTAs and economic cooperation within the development of international trade, we characterized the general behavior of PTAs, particularly highlighting their impact on the current configuration of FTAs within the multilateral trading system. In this way, and first, the total number of existing PTAs can be indicated, as seen in Table 2. This table covers the period after the end of World War II, precisely when international cooperation gained a prominent role in international relations and right after the signing of the GATT as a system of rules to regulate international trade. 
Table 2. Historical list of the preferential trade agreements (PTAs) registered under the World Trade Organization (WTO).

\begin{tabular}{|c|c|c|c|c|}
\hline $\mathbf{N}^{\circ}$ & Grantor & Name of the PTA & In Force Since & Duration \\
\hline 1 & United States & Former Trust Territory of the Pacific Islands & 1948 & Indefinite \\
\hline 2 & European Union & Generalized System of Preferences-European Union (EU) & 1971 & Indefinite \\
\hline 3 & Japan & Generalized System of Preferences-Japan & 1971 & Indefinite \\
\hline 4 & Norway & Generalized System of Preferences-Norway & 1971 & Indefinite \\
\hline 5 & New Zealand & Generalized System of Preferences-New Zealand & 1972 & Indefinite \\
\hline 6 & Switzerland & Generalized System of Preferences-Switzerland & 1972 & Indefinite \\
\hline 7 & Australia & Generalized System of Preferences-Australia & 1974 & Indefinite \\
\hline 8 & Canada & Generalized System of Preferences—Canada & 1974 & Indefinite \\
\hline 9 & United States & Generalized System of Preferences-United States & 1976 & Indefinite \\
\hline 10 & Australia & $\begin{array}{c}\text { Pacific Regional Trade and Economic } \\
\text { Cooperation Agreement }\end{array}$ & 1981 & Indefinite \\
\hline 11 & New Zealand & $\begin{array}{l}\text { Pacific Regional Trade and Economic } \\
\text { Cooperation Agreement }\end{array}$ & 1981 & Indefinite \\
\hline 12 & United States & Caribbean Basin Economic Recovery Act & 1984 & Indefinite \\
\hline 13 & Canada & Tariff Treatment for Commonwealth Caribbean countries & 1986 & Indefinite \\
\hline 14 & United States* & The Andean Trade Preference Act & 1991 & 2013 \\
\hline 15 & South Korea & Preferential Tariff for LDCs *- Republic of Korea & 2000 & Indefinite \\
\hline 16 & United States & African Growth and Opportunity Act & 2000 & Indefinite \\
\hline 17 & European Union & Trade Preferences for Western Balkan Countries & 2000 & Indefinite \\
\hline 18 & Morocco & Duty-free Treatment for African LDCs-Morocco & 2001 & Indefinite \\
\hline 19 & Turkey & Generalized System of Preferences-Turkey & 2002 & Indefinite \\
\hline 20 & Iceland & Generalized System of Preferences-Iceland & 2002 & Indefinite \\
\hline 21 & Tajikistan & Duty-free Treatment for LDCs-Tajikistan & 2003 & Indefinite \\
\hline 22 & Chinese Taipei & Duty-free Treatment for LDCs-Chinese Taipei & 2003 & Indefinite \\
\hline 23 & Kyrgyz Republic & Duty-free Treatment for LDCs-Kyrgyz Republic & 2006 & Indefinite \\
\hline 24 & European Union * & Trade Preferences for the Republic of Moldova & 2008 & 2015 \\
\hline 25 & India & Preferential Duty-free Treatment for LDCs & 2008 & Indefinite \\
\hline 26 & Kazakhstan & Generalized System of Preferences-Kazakhstan & 2010 & Indefinite \\
\hline 27 & Russia & Generalized System of Preferences-Russian Federation & 2010 & Indefinite \\
\hline 28 & China & Duty-free Treatment for LDCs—China & 2010 & Indefinite \\
\hline 29 & European Union * & Trade Preferences for Pakistan & 2012 & 2013 \\
\hline 30 & Chile & Duty-free Treatment for LDCs—Chile & 2014 & Indefinite \\
\hline 31 & Thailand & Duty-free Treatment for LDCs-Thailand & 2015 & Indefinite \\
\hline 32 & Armenia & Generalized System of Preferences-Armenia & 2016 & Indefinite \\
\hline 33 & United States* & Trade Preferences for Nepal & 2016 & 2025 \\
\hline 34 & Montenegro & Duty-free Treatment for LDCs-Montenegro & 2017 & Indefinite \\
\hline
\end{tabular}

Source: Own elaboration based on data from the WTO (2019b). Note: Least Developed Countries (LDCs).

* Non-renewed PTAs.

Although a total of 34 PTAs have been created within the multilateral trading system, three of these unilateral tariff preferences, specifically the "The Andean Trade Preferences Act", the "Trade Preferences for the Republic of Moldova", and the "Trade Preferences for Pakistan", have all expired at the will of their granting countries, the United States and the European Union. Moreover, "Trade Preferences for Nepal" is also expected to expire by 2025, following the announcement of its grantor, the United States. Thus, today, of the 34 existing PTAs, only 31 unilateral tariff preferences are in force, and it is expected that, in the next five years, another of these PTAs will disappear. This is possible for the other agreements in the case that their granting countries decide to allow expiration.

Second, PTAs are presented successively by number of beneficiary countries in Table 3, which highlights trade agreements of this nature that unilaterally grant important tariff preferences for developing countries. 
Table 3. List of PTAs by the number of beneficiary countries.

\begin{tabular}{|c|c|c|c|}
\hline $\mathbf{N}^{\circ}$ & Grantor & Name of PTA & $\mathbf{N}^{\circ}$ of Beneficiaries \\
\hline 1 & Australia & Generalized System of Preferences-Australia & 177 \\
\hline 2 & Russia & Generalized System of Preferences-Russian Federation & 154 \\
\hline 3 & Turkey & Generalized System of Preferences-Turkey & 153 \\
\hline 4 & Kazakhstan & Generalized System of Preferences-Kazakhstan & 153 \\
\hline 5 & Armenia & Generalized System of Preferences-Armenia & 151 \\
\hline 6 & New Zealand & Generalized System of Preferences-New Zealand & 141 \\
\hline 7 & Japan & Generalized System of Preferences-Japan & 133 \\
\hline 8 & Switzerland & Generalized System of Preferences-Switzerland & 123 \\
\hline 9 & United States & Generalized System of Preferences-United States & 120 \\
\hline 10 & Canada & Generalized System of Preferences-Canada & 104 \\
\hline 11 & European Union & Generalized System of Preferences-European Union & 88 \\
\hline 12 & Norway & Generalized System of Preferences-Norway & 83 \\
\hline 13 & Kyrgyz Republic & Duty-free Treatment for LDCs-Kyrgyz Republic & 49 \\
\hline 14 & South Korea & Preferential Tariff for LDCs- Republic of Korea & 48 \\
\hline 15 & Iceland & Generalized System of Preferences-Iceland & 48 \\
\hline 16 & India & Preferential Duty-Free Treatment for LDCs & 48 \\
\hline 17 & Chile & Duty-free Treatment for LDCs-Chile & 48 \\
\hline 18 & Montenegro & Duty-free Treatment for LDCs-Montenegro & 48 \\
\hline 19 & Chinese Taipei & Duty-free Treatment for LDCs-Chinese Taipei & 47 \\
\hline 20 & Thailand & Duty-free Treatment for LDCs-Thailand & 47 \\
\hline 21 & Tajikistan & Duty-free Treatment for LDCs-Tajikistan & 45 \\
\hline 22 & United States & African Growth and Opportunity Act & 40 \\
\hline 23 & China & Duty-free Treatment for LDCs-China & 38 \\
\hline 24 & Morocco & Duty-free Treatment for African LDCs-Morocco & 34 \\
\hline 25 & Canada & Tariff Treatment for Commonwealth Caribbean countries & 18 \\
\hline 26 & United States & Caribbean Basin Economic Recovery Act & 17 \\
\hline 27 & New Zealand & Pacific Regional Trade and Economic Cooperation Agreement & 13 \\
\hline 28 & Australia & Pacific Regional Trade and Economic Cooperation Agreement & 13 \\
\hline 29 & European Union & Trade Preferences for Western Balkan Countries & 6 \\
\hline 30 & United States & Former Trust Territory of the Pacific Islands & 4 \\
\hline 31 & United States & The Andean Trade Preference Act & 1 \\
\hline 32 & United States & Trade Preferences for Nepal & 1 \\
\hline 33 & European Union & Trade Preferences for the Republic of Moldova & 1 \\
\hline 34 & European Union & Trade Preferences for Pakistan & 1 \\
\hline
\end{tabular}

Source: Own elaboration based on data from the WTO (2019b).

Hence, it is possible to highlight that within all these PTAs, the "Generalized System of Preferences-Australia" stands out with almost the total number of States in the world as beneficiaries. Others, such as the "Generalized System of Preferences—Russian Federation", the "Generalized System of Preferences-Turkey", the "Generalized System of Preferences-Kazakhstan", the "Generalized System of Preferences-Armenia", the "Generalized System of Preferences-New Zealand", and the "Generalized System of Preferences-Japan", present more than two thirds of the existing countries in addition to as many PTAs.

Third, PTAs can also be recognized on the basis of the preferences granted (see Table 4). In this case, trade agreements of this type that represent greater benefits for those developing countries that wish to export to these granting markets are prominent, according to the tariff universe ${ }^{2}$.

2 The term tariff universe refers exclusively to all goods that can be imported within a particular market or country and which may or may not, depending on the trade agreements signed as well as the level of competitiveness, enjoy tariff preferences within each product line or category. In this case, the PTAs include many different products that receive these tariff preferences from a grantor. The latter excludes certain strategic good for the internal economy of the grantor where the tariff protectionism is not reduced for developing countries. 
Table 4. List of PTAs by the preferences from grantors.

\begin{tabular}{|c|c|c|c|c|c|}
\hline $\mathbf{N}^{\circ}$ & Grantor & Name of PTA & $\begin{array}{c}\text { Tariff } \\
\text { Universe }\end{array}$ & $\begin{array}{l}\text { Universe with } \\
\text { Preferences }\end{array}$ & $\%$ \\
\hline 1 & Chile & Duty-free Treatment for LDCs-Chile & 8559 & 8450 & $98.70 \%$ \\
\hline 2 & India & Preferential Duty-free Treatment for LDCs & 11,546 & 10,949 & $94.80 \%$ \\
\hline 3 & China & Duty-free Treatment for LDCs-China & 8547 & 7527 & $88.10 \%$ \\
\hline 4 & South Korea & Preferential Tariff for LDCs- Republic of Korea & 12,232 & 8972 & $73.30 \%$ \\
\hline 5 & European Union & Trade Preferences for the Republic of Moldova & 9533 & 6954 & $72.90 \%$ \\
\hline 6 & Canada & Tariff Treatment for Commonwealth Caribbean countries & 6827 & 4805 & $70.40 \%$ \\
\hline 7 & Armenia & Generalized System of Preferences-Armenia & 9189 & 6179 & $67.20 \%$ \\
\hline 8 & Switzerland & Generalized System of Preferences-New Zealand & 8523 & 5609 & $65.80 \%$ \\
\hline 9 & European Union & Generalized System of Preferences-European Union & 9533 & 6160 & $64.60 \%$ \\
\hline 10 & United States & African Growth and Opportunity Act & 10,898 & 6466 & $59.30 \%$ \\
\hline 11 & Tukey & Generalized System of Preferences-Turkey & 16,511 & 9387 & $56.90 \%$ \\
\hline 12 & Kyrgyz Republic & Duty-free Treatment for LDCs-Kyrgyz Republic & 10,991 & 5879 & $53.50 \%$ \\
\hline 13 & Australia & $\begin{array}{c}\text { Pacific Regional Trade and Economic } \\
\text { Cooperation Agreement }\end{array}$ & 6474 & 3384 & $52.30 \%$ \\
\hline 14 & New Zealand & $\begin{array}{c}\text { Pacific Regional Trade and Economic } \\
\text { Cooperation Agreement }\end{array}$ & 6474 & 3384 & $52.30 \%$ \\
\hline 15 & Australia & Generalized System of Preferences-Australia & 6474 & 3283 & $50.70 \%$ \\
\hline 16 & United States & The Andean Trade Preference Act & 10,514 & 5037 & $47.90 \%$ \\
\hline 17 & United States & Caribbean Basin Economic Recovery Act & 10,898 & 5158 & $47.30 \%$ \\
\hline 18 & Japan & Generalized System of Preferences-Japan & 9147 & 3032 & $33.10 \%$ \\
\hline 19 & United States & Generalized System of Preferences-United States & 10,898 & 3517 & $32.30 \%$ \\
\hline 20 & Russia & Generalized System of Preferences-Russian Federation & 11,610 & 2472 & $21.30 \%$ \\
\hline 21 & Canada & Generalized System of Preferences-Canada & 6827 & 1188 & $17.40 \%$ \\
\hline 22 & Norway & Generalized System of Preferences-Norway & 7179 & 922 & $12.80 \%$ \\
\hline 23 & New Zealand & Generalized System of Preferences-New Zealand & 7926 & 473 & $6.00 \%$ \\
\hline 24 & Iceland & Generalized System of Preferences-Iceland & 8981 & 323 & $3.60 \%$ \\
\hline 25 & Chinese Taipei & Duty-free Treatment for LDCs-Chinese Taipei & 9137 & 143 & $1.60 \%$ \\
\hline 26 & Morocco & Duty-free Treatment for African LDCs-Morocco & 18,272 & 232 & $1.30 \%$ \\
\hline 27 & European Union & Trade Preferences for Pakistan & 9376 & 53 & $0.60 \%$ \\
\hline 28 & United States & Former Trust Territory of the Pacific Islands & NI & NI & NI \\
\hline 29 & United States & Trade Preferences for Nepal & NI & NI & NI \\
\hline 30 & Kazakhstan & Generalized System of Preferences-Kazakhstan & NI & NI & NI \\
\hline 31 & Montenegro & Duty-free Treatment for LDCs-Montenegro & $\mathrm{NI}$ & NI & NI \\
\hline 32 & Thailand & Duty-free Treatment for LDCs-Montenegro-Thailand & NI & NI & NI \\
\hline 33 & Tajikistan & Duty-free Treatment for LDCs-Tajikistan & NI & NI & NI \\
\hline 34 & European Union & Trade Preferences for Western Balkan Countries & NI & $\mathrm{NI}$ & NI \\
\hline
\end{tabular}

Source: Own elaboration based on data from the WTO (2019b). Note: No information available (NI).

Therefore, currently, within all existing PTAs, seven of them, namely the "Tariff Duty Free Treatment for LDCs-Chile", the "Tariff Duty Free Preferential Regime for LDCs", the "Duty-free Treatment for LDCs-China", the "Preferential Tariff for LDCs-Republic of Korea", the "Trade Preferences of the Republic of Moldova", the "Tariff of Caribbean Commonwealth Countries", and the "Generalized System of Preferences-Armenia", reach more than two thirds of preferences for their entire tariff universe, thus standing out among all other unilateral trade agreements that grant this type of benefits related to international cooperation.

Fourth and last, the PTAs that generated new FTAs can be identified in Table 5. This highlights some grantors as well as economic blocks that have signed various commercial agreements of bilateral and/or reciprocal typology with their former beneficiary countries. 
Table 5. List of PTAs resulting in the creation of FTAs.

\begin{tabular}{|c|c|c|c|c|c|}
\hline Grantor & Name of PTA & $\mathbf{N}^{\circ}$ & FTA & Signed in & In Force Since \\
\hline \multirow{6}{*}{$\begin{array}{l}\text { European } \\
\text { Union }\end{array}$} & $\begin{array}{l}\text { Trade Preferences for the } \\
\text { Republic of Moldova }\end{array}$ & 1 & EU_Moldova & 2014 & 2014 \\
\hline & $\begin{array}{c}\text { Generalized System of } \\
\text { Preferences-European Union }\end{array}$ & 2 & EU_Colombia and Peru & 2012 & 2013 \\
\hline & \multirow{4}{*}{$\begin{array}{c}\text { Trade Preferences for Western } \\
\text { Balkan Countries }\end{array}$} & 3 & EU-North Macedonia & 2001 & 2004 \\
\hline & & 4 & EU_Albania & 2006 & 2009 \\
\hline & & 5 & EU-Montenegro & 2007 & 2010 \\
\hline & & 6 & EU—Serbia & 2008 & 2013 \\
\hline \multirow{5}{*}{ Australia } & \multirow{5}{*}{$\begin{array}{l}\text { Generalized System of } \\
\text { Preferences-Australia }\end{array}$} & 7 & $\begin{array}{l}\text { Australia-Papua New } \\
\text { Guinea (PATCRA) }\end{array}$ & 1976 & 1977 \\
\hline & & 8 & Australia-Singapore & 2003 & 2003 \\
\hline & & 9 & Australia-Thailand & 2004 & 2005 \\
\hline & & 10 & Australia-Chile & 2008 & 2009 \\
\hline & & 11 & Australia-Malaysia & 2012 & 2013 \\
\hline \multirow{5}{*}{ Turkey } & \multirow{5}{*}{$\begin{array}{l}\text { Generalized System of } \\
\text { Preferences-Turkey }\end{array}$} & 12 & Turkey-Tunisia & 2004 & 2005 \\
\hline & & 13 & Turkey-Albania & 2006 & 2008 \\
\hline & & 14 & Turkey-Serbia & 2009 & 2010 \\
\hline & & 15 & Turkey-Jordan & 2009 & 2011 \\
\hline & & 16 & Turkey-Malaysia & 2014 & 2015 \\
\hline \multirow{4}{*}{ United States } & \multirow{2}{*}{$\begin{array}{c}\text { The Andean Trade Preference } \\
\text { Act }\end{array}$} & 17 & $\begin{array}{c}\text { United } \\
\text { States-Colombia }\end{array}$ & 2006 & 2009 \\
\hline & & 18 & United States-Peru & 2006 & 2012 \\
\hline & $\begin{array}{c}\text { Generalized System of } \\
\text { Preferences-United States }\end{array}$ & 19 & United States-Jordan & 2000 & 2001 \\
\hline & $\begin{array}{c}\text { Caribbean Basin Economic } \\
\text { Recovery Act }\end{array}$ & 20 & $\begin{array}{c}\text { Dominican } \\
\text { Republic-Central } \\
\text { America-United States } \\
\text { Free Trade agreement } \\
\text { (CAFTA-DR) }\end{array}$ & 2004 & 2006 \\
\hline \multirow{3}{*}{ Japan } & \multirow{3}{*}{$\begin{array}{l}\text { Generalized System of } \\
\text { Preferences-Japan }\end{array}$} & 21 & Japan-Philippines & 2006 & 2008 \\
\hline & & 22 & Japan-Peru & 2011 & 2012 \\
\hline & & 23 & Japan-Mongolia & 2015 & 2016 \\
\hline \multirow{2}{*}{ India } & Preferential Duty-Free & 24 & India-Afghanistan & 2003 & 2003 \\
\hline & Treatment for LDCs & 25 & India-Bhutan & 2006 & 2006 \\
\hline \multirow{2}{*}{ New Zealand } & \multirow{2}{*}{$\begin{array}{c}\text { Generalized System of } \\
\text { Preferences-New Zealand }\end{array}$} & 26 & New Zealand-Malaysia & 2009 & 2010 \\
\hline & & 27 & New Zealand-Thailand & 2005 & 2005 \\
\hline \multirow[b]{2}{*}{ Tajikistan } & \multirow[t]{2}{*}{$\begin{array}{l}\text { Duty-free Treatment for } \\
\text { LDCs-Tajikistan }\end{array}$} & 28 & $\begin{array}{l}\text { Tajikistan-Ukraine } \\
\text { Treaty on a Free Trade }\end{array}$ & 2001 & 2002 \\
\hline & & 29 & $\begin{array}{l}\text { area between members } \\
\text { of the Commonwealth of } \\
\text { Independent States (CIS) }\end{array}$ & 2011 & 2012 \\
\hline Canada & $\begin{array}{l}\text { Generalized System of } \\
\text { Preferences-Canada }\end{array}$ & 30 & Canada-Honduras & 2013 & 2014 \\
\hline Kazakhstan & $\begin{array}{l}\text { Generalized System of } \\
\text { Preferences-Kazakhstan }\end{array}$ & 31 & $\begin{array}{l}\text { Eurasian Economic } \\
\text { Union } \\
\text { (EAEU)-Vietnam }\end{array}$ & 2015 & 2016 \\
\hline Russia & $\begin{array}{l}\text { Generalized System of } \\
\text { Preferences-Russian } \\
\text { Federation }\end{array}$ & 32 & Russia-Serbia & 2000 & 2006 \\
\hline
\end{tabular}

Source: Own elaboration based on data from the WTO (2019b).

\section{Conclusions}

PTAs originated from the post-war period as instruments for international cooperation after the GATT was signed and were partially protected by Articles XVIII and XXIV. It was only in the late 1970s, through the "Enabling Clause" developed in the Tokyo Round, that such unilateral trade agreements were consolidated after the application of the MFN principle included in GATT Article I was excluded.

The top ten PTA grantors in the world, including countries such as Australia, Russia, Turkey, Kazakhstan, Armenia, New Zealand, Japan, Switzerland, the United States, and Canada, grant unilateral 
tariff preferences to more than half of the developing countries in the world. However, the current dynamics of international trade have resulted in the creation of a total of 32 FTAs out of the current 31 PTAs, redefining the entire essence of S\&D.

Therefore, there is a clear lack of interest in developed countries to continue granting S\&D through new PTAs within the multilateral trading system. This trend renders the decline in cooperation within international relations through the signing of new FTAs latent. We emphasize that this situation may in fact be the result of the dependence created by the PTAs in developing economies, which tend to consider the negotiating and signing of FTAs necessary so as to not lose certain tariff benefits in case that the PTAs are not renewed by the grantors. PTAs are not always an instrument of international cooperation exclusively of the developed countries as countries that have not reached this economic status may also grant unilateral tariff concessions through PTAs.

Future lines of research could potentially deal with the reasons behind the lack of continuing S\&D-granting through PTAs to developing countries, as this is due to countless additional causes.

The new shift in the foreign trade policy approach adopted by developed countries could respond to a change in the circumstances of both developing and developed countries. Developing countries could improve their economic indicators, which would invite developed countries to treat them with greater reciprocity. Developing countries could act as trading partners at a level similar to developed countries, thus, providing both groups with positive results in commercial terms. PTAs, in this context, would be losing their relevance.

The paradigm of international cooperation was influenced by the 2008 crisis as there still exist some vestiges of protectionism left by the "Great Recession", which prompted developed countries to not renew pre-crisis trade privileges. This scenario, where PTAs lose relevance, could become more acute in the current context of crisis due to the current global public health issue of COVID-19, which could influence a shift of remaining PTAs to FTAs in the post-pandemic period. This may be done in an attempt to recover the economies of many different countries considering the new challenges for international trade.

Author Contributions: Introduction J.J.B.-R. and S.H.-O.; Literature review J.J.B.-R. and S.H.-O.; Methodology; J.J.B.-R. and S.H.-O.; Results and Discussion J.J.B.-R.; Conclusions S.H.-O. All authors have read and agreed to the published version of the manuscript.

Funding: This research received no external funding.

Conflicts of Interest: The authors declare no conflict of interest.

\section{References}

Acharya, Sushant, and Julien Bengui. 2018. Liquidity traps, capital flows. Journal of International Economics 114: 276-98. [CrossRef]

Ajami, Riad A., Karel Cool, G. Jason Goddard, and Dara Khambata. 2006. International Business: Theory and Practice. New York: M. E. Sharpe.

Axelrod, Robert, and Robert O. Keohane. 1985. Achieving Cooperation under Anarchy: Strategies and Institutions. World Politics 38: 226-54. [CrossRef]

Baena, Jose. 2018. Barreras arancelarias y no arancelarias como restricciones al comercio internacional. Revista Venezolana de Gerencia 83: 543-62.

Baena, Jose. 2019. Proteccionismo inverso y política comercial dentro del sistema multilateral de comercio: el caso de las restricciones a la exportación. Estudos Internacionais: Revista De relações Internacionais Da PUC Minas 7: 28-50. [CrossRef]

Baena, Jose. 2020. Transición de los sistemas generalizados de preferencias un cambio de política en cooperación internacional. Semestre Económico 23: 61-83. [CrossRef]

Baena, Jose, and Giovanny Cardona. 2019. Unión Europea y Japón: ¿El tratado de libre comercio más grande del mundo? Revista de Ciencias Socials (RCS) 15: 62-81.

Baena, Jose, and Xavier Fernández. 2016. Aproximaciones a la inserción de Colombia en el sistema multilateral de comercio en 1995-2015. Análisis Político 29: 114-31. [CrossRef] 
Baena, Jose, and Abraham Londoño. 2020. Tariff barriers and non-tariff barriers: appraising Colombia's protectionism. World Customs Journal 14: 71-94.

Baena, Jose, Anlly Montoya, and Dayana Torres. 2017. La crisis económica mundial ¿La proliferación del proteccionismo como una causa-efecto? En-Contexto 5: 185-207.

Baier, Scott L., and Jeffrey H. Bergstrand. 2007. Do free trade agreements actually increase members' international trade? Journal of International Economics 71: 72-95. [CrossRef]

Balassa, Bela. 2013. The Theory of Economic Integration. New York: Routledge.

Baldwin, Richard. 1993. A Domino Theory of Regionalism. NBER Working Paper 4465. Cambridge: National Bureau of Economic Research.

Baldwin, Richard, and Simon Evenett. 2008. The Crisis and Protectionism: Steps World Leaders Should Take. Available online: https://voxeu.org/article/crisis-and-protectionism-steps-world-leaders-should-take (accessed on 20 July 2020).

Baldwin, Richard, and Dany Jaimovich. 2012. Are Free Trade Agreements contagious? Journal of International Economics 88: 1-16. [CrossRef]

Bartels, Lorand. 2003. The WTO enabling clause and positive conditionally in the European community's GSP program. Journal of International Economic Law 6: 507-32. [CrossRef]

Bartels, Lorand, and Federeico Ortino. 2006. Regional Trade Agreements and the WTO Legal System. New York: Oxford University Press.

Bearce, David H. 2003. Grasping the commercial institutional peace. International Studies Quarterly 47: 347-70. [CrossRef]

Bhagwati, Jagdish. 2008. Termites in the Trading System: How Preferential Agreements Undermine Free Trade. New Delhi: Oxford University Press.

Bhagwati, Jagdish, and Arvind Panagariya. 1996. Preferential Trading Areas and Multilateralism: Strangers, Friends or Foes? The Economics of Preferential Trade Agreements. Discussion Paper Series No. 9596-04; Washington: AEI Press.

Büthe, Tim, and Helen V. Milner. 2008. The politics of foreign direct investment into developing countries: Increasing FDI through international trade agreements? American Journal of Political Science 52: 741-62. [CrossRef]

Cardona, Giovanny. 2015. La Organización Mundial del Comercio y los TLC ¿reinventando el Sistema Multilateral de Comercio? Medellín: Editorial CEIPA.

Cardona, Giovanny. 2017. Comercio Mundial tendencias y estructura. Medellín: Editorial CEIPA.

Cassimatis, Anthony. 2011. Developing countries, trade, and human rights: Free trade agreements, development needs, and the European Union's generalized system of preferences. In Law and Development Perspective on International Trade Law. Edited by Yong-Shik Lee, Gary Horlick, Won-Mog Choi and Tomer Broude. Queensland: Cambridge University Press, pp. 227-96.

Cassis, Youssef. 2011. Crises and Opportunities: The Shaping of Modern Finance. New York: Oxford University Press.

CBP. 2020. Generalized System of Preferences (GSP). U.S. Customs and Border Protection. Available online: https://www.cbp.gov/trade/priority-issues/trade-agreements/special-trade-legislation/generalized -system-preferences (accessed on 11 May 2020).

Cheong, Juyoung, Do Won Kwak, and Kam Ki Tang. 2018. The trade effects of tariffs and non-tariff changes of preferential trade agreements. Economic Modelling 70: 370-82. [CrossRef]

Crawford, Jo-Ann, and Sam Laird. 2001. Regional trade agreements and the WTO. The North American Journal of Economics and Finance 12: 193-211. [CrossRef]

De Boyrie, Maria E., and Roger Johns. 2013. The effects of trade agreements on the growth of major Latin American economies. The Journal of International Trade E Economic Development 22: 377-97.

De la Reza, Germán A. 2015. Art. XXIV del GATT-OMC: La relación entre regionalismo y multilateralismo. Problemas del Desarrollo 46: 185-204. [CrossRef]

Denzin, Norman, and Lincoln Yvonna. 2005. The Sage Handbook of Qualitative Research. London: Sage Publications Ltd.

Diez, Alfredo. 2001. Trato especial y diferenciado para países en desarrollo. Themis 43: 249-59.

Dos Santos, Norma Breda, Rogerio Farias, and Raphael Cunha. 2005. Generalized System of Preferences in General Agreement on Tariffs and Trade/World Trade Organization: History and current issues. Journal of World Trade 39: 637-70. 
Duarte, Lisbeth, and Carlos González. 2015. Origin and Evolution of International Cooperation for Development. Panorama 8: 117-31.

Estevadeordal, Antoni, and Kati Suominen. 2009. The Sovereign Remedy?: Trade Agreements in a Globalizing World. New York: Oxford University Press.

European Parliament. 2018. The historical development of European integration. Fact Sheets on the European Union. Available online: http://www.europarl.europa.eu/RegData/etudes/PERI/2018/618969/IPOL_PERI(2018)61896 9_EN.pdf (accessed on 11 May 2020).

Evenett, Simon, and Johannes Fritz. 2018. Brazen Unilateralism: The US-China Tariff War in Perspective. The 23rd Global Trade Alert Report. Centre for Economic Policy Research Press. Available online: https://www.global tradealert.org/reports/45 (accessed on 20 July 2020).

Fernández, Xavier. 2009. Globalización Económica, Soberanía De Los Estados Y Políticas Sociales: Funciones y Retos Del Derecho Internacional Ante El “Trilema” De La Globalización. Sociedad Global 3: 43-84.

Fiorentino, Roberto V, Luis Verdeja, and Christelle Toqueboeuf. 2007. The Changing Landscape of Regional Trade Agreements: 2006 Update. WTO Discussion Paper, No. 12. Geneva: World Trade Organization (WTO).

Giddens, Anthony, and Sutton Phillip. 2013. Sociology. London: Polity Press.

Giordano, Paolo, Mauricio Mesquita, and Fernando Quevedo. 2004. El Tratamiento de las Asimetrías en los Acuerdos de Integración Regional. INTAL_ITD Documento de Divulgación 26. Available online: https://publications.iadb.org/publications/spanish/document/El-tratamiento-de-las-asimetr\%C3\%A Das-en-los-acuerdos-de-integraci\%C3\%B3n-regional.pdf (accessed on 20 July 2020).

Gisselquist, Rachel M. 2014. Paired comparison and theory development: Considerations for case selection. PS: Political Science \& Politics 47: 477-84.

Hartman, Stephen W. 2013. The WTO, the Doha Round Impasse, PTAs, and FTAs/RTAs. The International Trade Journal 27: 411-30. [CrossRef]

Hassan, Kabir. 2001. Is SAARC a viable economic block? Evidence from gravity model. Journal of Asian Economics 12: 263-90. [CrossRef]

Healy, Marilyn, and Chad Perry. 2000. Comprehensive criteria to judge validity and reliability of qualitative research within the realism paradigm. Qualitative Market Research: An International Journal 3: 118-26. [CrossRef]

Hollenberg, Jord. 2003. Rules of Origin in the WTO and in Other Free Trade Agreements-An Overwiew. Norderstedt: GRIN Verlag.

Ito, Takatoshi, and Anne O. Krueger. 1993. Trade and Protectionism. Chicago: The University Chicago Press.

Jovanović, Miroslav N. 1998. International Economic Integration: Theory and Measurement. London: Routledge.

Kembayev, Zhenis. 2009. Legal Aspects of the Regional Integration Processes in the Post-Soviet Area. Berlin: Springer.

Kemp, Murray C., and Henry Y. Wan Jr. 1976. An elementary proposition concerning the formation of customs unions. Journal of International Economics 6: 95-97. [CrossRef]

Kennedy, Kevin C. 2011. The Generalized System of Preferences after Four Decades: Conditionality and the Shrinking Margin of Preference. Michigan State University College of Law Journal of International Law 9: 1-227.

Kinoshita, Fernando, and Patricia Barbosa. 2016. Análisis de las normas aplicables a los acuerdos comerciales regionales en materia de mercancías. Revista Jurídica da Presidência 17: 471-94. [CrossRef]

Kolb, Robert W. 2008. Encyclopedia of Business Ethics and Society. London: SAGE publications.

Lacarte, Julio, and Jaime Granados. 2004. Solución de Controversias Comerciales e Inter-Gubernamentales: Enfoques Multilaterales y Regionales. Buenos Aires: BID-INTAL.

Lake, David. 1996. Anarchy, hierarchy, and the variety of international relations. International Organization 50: 1-33. [CrossRef]

Lake, David. 2009. Hobbesian hierarchy: The political economy of political organization. Annual Review of Political Science 12: 263-83. [CrossRef]

Lake, David. 2011. Hierarchy in International Relations. Ithaca: Cornell University Press.

Lavopa, Federico. 2012. ¿El regreso a las represalias comerciales unilaterales? Reflexiones sobre la legalidad de la utilización de los sistemas generalizados de preferencias como instrumento de presión internacional. Facultad Latinoamericana de Ciencias Sociales_Cátedra OMC FLACSO Argentina. Available online: http: //catedraomc.flacso.org.ar/wp-content/uploads/2012/08/FLA_OMC_RepresaliasComerciales.pdf (accessed on 20 July 2020). 
Lavopa, Federico, and Demián Dalle. 2012. ¿Hay vida después del SGP? Implicancias de la posible exclusión de Argentina de los sistemas generalizados de preferencias de Estados Unidos y la Unión Europea. Facultad Latinoamericana de Ciencias Sociales_Cátedra OMC FLACSO Argentina. Available online: https://eulacfoundation.org/es/system/files/HAY\%20VIDA\%20DESPU\%C3\%89S\%20DEL\%20SGP\%20IMP LICANCIAS\%20DE\%20LA\%20POSIBLE\%20EXCLUSI\%C3\%93N\%20DE\%20ARGENTINA\%20DE\%20L OS\%20SISTEMAS\%20GENERALIZADOS\%20DE\%20PREFERENCIAS\%20DE\%20EEUU.pdf (accessed on 11 May 2020).

Mansfield, Edward D., and Jon C. Pevehouse. 2000. Trade blocs, trade flows, and international conflict. International Organization 54: 775-808. [CrossRef]

Mansfield, Edward D., Helen V. Milner, and B. Peter Rosendorff. 2002a. Why democracies cooperate more: Electoral control and international trade agreements. International Organization 56: 477-513. [CrossRef]

Mansfield, Edward D., Helen V. Milner, and B. Peter Rosendorff. 2002b. Replication, realism, and robustness: Analyzing political regimes and international trade. American Political Science Review 96: 167-69. [CrossRef]

Mansfield, Edward D., Helven V. Milner, and Jon C. Pevehouse. 2008. Democracy, veto players and the depth of regional integration. World Economy 31: 67-96. [CrossRef]

Martin, Lisa. 2015. The Oxford Handbook of the Political Economy of International Trade. Oxford: Oxford University Press.

Martin, Philippe, Thierry Mayer, and Mathias Thoenig. 2010. The Geography of Conflicts and Free Trade Agreements. CEPR Discussion Paper 7740. London: CEPR Centre for Economic Policy Research.

Milewicz, Karolina, James Hollway, Claire Peacock, and Duncan Snidal. 2018. Beyond Trade: The Expanding Scope of the Nontrade Agenda in Trade Agreements. Journal of Conflict Resolution 62: 743-73. [CrossRef]

Missios, Paul, Kamal Saggi, and Halis Murat Yildiz. 2016. External trade diversion, exclusion incentives and the nature of preferential trade agreements. Journal of International Economics 99: 105-19. [CrossRef]

OECD. 2005. Preferential Trading Arrangements In Agricultural and Food Markets: The Case of the European Union and the United States. Paris: Organisation for Economic Cooperation and Development.

Panagariya, Arvind. 2002. EU Preferential Trade Arrangements and Developing Countries. The World Economy 25: 1415-32. [CrossRef]

Pardo, Germán. 2014. Acuerdos Comerciales y Aspectos Relacionados Con el Comercio Exterior. Bogotá: Editorial Universidad del Rosario.

Piérola, Fernando. 2002. Los sistemas unilaterales de preferencias arancelarias y el principio de no discriminación en el Derecho de la Organización Mundial del Comercio. Agenda Internacional 8: 103-28.

Quecedo, Rosario, and Carlos Manuel Castaño. 2002. Introducción a la metodología de investigación cualitativa. Revista de Psicodidáctica 14: 5-39.

Ramadan, Mohamed. 2010. United States Bilateral Free Trade Agreements: Consistencies or Conflicts with Norms in the Middle East? New York: Kluwer Law International.

Rosales, Osvaldo. 2009. Crisis Internacional y Oportunidades para la Cooperación Regional. Santiago de Chile: CEPAL.

Rose, Andrew K. 2004. Do we really know that the WTO increases trade? American Economic Review 94: 98-114. [CrossRef]

Sánchez, Victor M. 2010. Derecho Internacional Público. Barcelona: Huygens Editorial.

Sapir, Andre. 1981. Trade benefits under the EEC generalized system of preferences. European Economic Review 15: 339-55. [CrossRef]

SUBREI. 2019. Glosario de comercio internacional y definiciones contenidas en los acuerdos comerciales. Subsecretaría de Relaciones Económicas Internacionales. Available online: https://www.subrei.gob.cl/glosario/ (accessed on 11 May 2020).

Tobin, Jennifer L., and Marc L. Busch. 2019. The Disadvantage of Membership: How Joining the GATT/WTO Undermines GSP. World Trade Review 18: 109-32. [CrossRef]

Trejos, Alberto. 2009. Instrumentos para la Evaluación del Impacto de Acuerdos Comerciales. Ciudad de México: CEPAL.

Tugores, Juan. 2002. Economía Internacional. Barcelona: Editorial Mac Graw-Hill.

Ugarte Vega-Centeno, Máximo. 1996. Cooperación internacional y desarrollo en las Naciones Unidas. Agenda Internacional 3: 79-115. 
UNESCAP. 2019. Preferential Trade and Agreements: An Update. United Nations Economic and Social Commission for Asia and the Pacific. Available online: https://www.unescap.org/sites/default/files/aptir-2016-ch6.pdf (accessed on 11 May 2020).

Urata, Shujiro. 2002. Globalization and the growth in free trade agreements. Asia-Pacific Review 9: $20-32$. [CrossRef]

USTR. 2018. U.S. Generalized System of Preferences: GUIDEBOOK. The Office of the United States Trade Representative. Available online: https://ustr.gov/sites/default/files/files/gsp/GSP\%20Guidebook\%20April\%202018.pdf (accessed on 11 May 2020).

Vanegas, Juan, and Jose Baena. 2019. Virtual protectionism: Overview of MFN tariffs and bound tariffs in South America. Journal of International Studies 12: 63-78.

Vicard, Vincent. 2008. Trade, Conflicts and Political Integration: Explaining the Heterogeneity of Regional Trade Agreements. CES Working Papers 2008.22. Paris: Centre National de la Recherche Scientifique.

Whalley, John. 1998. Why Do Countries Seek Regional Trade Agreements? In The Regionalization of the World Economy. Edited by Jeffrey A. Frankel. Chicago: University of Chicago Press, pp. 63-90.

WTO. 2011. World Trade Report 2011. The WTO and Preferential Trade Agreements: From Co-Existence to Coherence. World Trade Organization. Available online: https://www.wto.org/english/res_e/booksp_e/anrep _e/world_trade_report11_e.pdf (accessed on 11 May 2020).

WTO. 2019a. Regional Trade Agreements and Preferential Trade Arrangements. Trade Topics. Available online: https://www.wto.org/english/tratop_e/region_e/rta_pta_e.htm (accessed on 11 May 2020).

WTO. 2019b. Regional Trade Agreements Database. World Trade Organization. Available online: https://rtais.wto.or g/UI/PublicMaintainRTAHome.aspx (accessed on 11 May 2020).

Wu, Jennifer Pédussel. 2004. Measuring and Explaining Levels of Regional Economic Integration. ZEI Working Paper B12/2004. Bonn: Rheinische Friedrich-Wilhelms-Universität Bonn, Zentrum für Europäische Integrationsforschung (ZEI).

(C) 2020 by the authors. Licensee MDPI, Basel, Switzerland. This article is an open access article distributed under the terms and conditions of the Creative Commons Attribution (CC BY) license (http://creativecommons.org/licenses/by/4.0/). 